\title{
PENERAPAN ASAS PERSONALITAS KEISLAMAN DI PENGADILAN AGAMA PONTIANAK DALAM PERKARA PERKAWINAN BAGI PASANGAN YANG BERALIH AGAMA
}

\author{
Etika Rahmawati \\ Sekolah Tinggi Ilmu Syariah Syarif Abdurrahman Pontianak \\ Jl. Sungai Raya Dalam Nomor 16B, Pontianak, Kalimantan Barat \\ E-mail: etikarahmawati91@gmail.com
}

\begin{abstract}
Islamic Personality principle is the main principle included in Religious Court Law with the meaning that the parties as the subjects and can be subjected to the authority in the environtment of Religious Court are those who adhere Islamic Religion. It can be said that the Islamic person on which the authority of the Religious and in other words, a non-Muslim faiths is not subject and can't be forced to submit to the authority in the Religious Court. The application of this principle has always been associated with civil lawsuits (a particular field), such as field matters relating to marriage, both in terms of divorce, cancellation and so on. In the case study Supreme Court Decree Number 726K / SIP / 1976 there is a violation of Islamic Personality principle in the case of marriage cancellation that resulted in the difference in perspective between the two institutions, namely the judiciary Religious Court and District Court. Based on the decision needs to be pursued further concerning the application of Islamic Personality principle in Pontianak Religious Court especially with regard to matter of marriage for couple who changing religion. The research method used in this paper was normative-juridical (Doctrinal Research) by the research specification of analytical-descriptive. The aims of this paper writing were people can know about Islamic Personality principle by the looking at the background of Islamic Personality principle in the aspects of Islamic law and the existence of several theories prior to the implementation of Islamic Personality principle, such as the theory of Receptio In Complexu are interrelated and interconnected with Islamic Personality principle, so that the application of Islamic Personality principle can be seen in the environment for the Islamic Religious Court in Pontianak has been applied in accordance with the provisions of Regulation in Indonesian or the violation of Islamic Personality principle still happening in Indonesian.
\end{abstract}

Keywords : Islamic Personality Principle, Religious Court, Marriage, Changing Religion.

\begin{abstract}
Abstrak
Asas Personalitas Keislaman adalah asas utama yang melekat pada Undang-Undang Peradilan Agama yang memberikan makna bahwa pihak yang tunduk dan dapat ditundukkan kepada kekuasaan di lingkungan Peradilan Agama adalah hanya mereka yang beragama Islam. Dapat dikatakan bahwa Keislaman seseoranglah yang menjadi dasar kewenangan Peradilan Agama dan dengan kata lain, seorang penganut agama non-Islam tidak tunduk dan tidak dapat dipaksakan tunduk kepada kekuasaan Peradilan Agama. pemberlakuan Asas ini selalu dikaitkan dengan perkara perdata (bidang tertentu), seperti bidang perkara yang berkaitan dengan hal Perkawinan, baik dalam hal perceraian, pembatalan dan sebagainya. Dalam studi kasus Putusan MA No. 726K/SIP/1976 terdapat suatu pelanggaran asas personalitas keislaman dalam perkara pembatalan perkawinan yang mengakibatkan adanya perbedaan sudut pandang antar dua lembaga peradilan yaitu Pengadilan Agama dan Pengadilan Negeri. Berdasarkan putusan tersebut perlu ditelusuri lebih lanjut mengenai penerapan asas
\end{abstract}


personalitas keislaman di lingkungan Pengadilan Agama Pontianak khususnya yang berkaitan dengan perkara perkawinan bagi pasangan yang beralih agama. Metode yang digunakan dalam penulisan ini adalah pendekatan yuridis normatif (Doctrinal Research) dengan spesifikasi penelitian yang bersifat deskriptif analitis. Tujuan dari penulisan ini agar masyarakat dapat mengetahui tentang asas personalitas keislaman dengan melihat latar belakang asas personalitas keislaman dalam aspek Hukum Islam dan keberadaan beberapa teori sebelum pemberlakuan asas personalitas keislaman ini, seperti teori Receptio In Complexu yang memiliki keterkaitan dan saling berhubungan dengan asas personalitas Keislaman, sehingga dapat dilihat penerapan asas personalitas keislaman yang ada di lingkungan Pengadilan Agama Pontianak telah diterapkan sesuai dengan ketentuan Peraturan Perundang-Undangan di Indonesia atau masih ada pelanggaran yang terjadi pada asas personalitas keislaman di Indonesia.

Kata Kunci : Asas Personalitas Keislaman, Pengadilan Agama, Perkawinan, Beralih Agama.

\section{PENDAHULUAN}

Peradilan Agama sudah ada di Indonesia sejak jaman kerajaan-kerajaan. Di beberapa daerah tertentu di Indonesia, agama Islam tidak hanya menjadi agama resmi atau agama negara bahkan hukum yang diberlakukan di daerah tersebut adalah hukum Islam, seperti kerajaan Islam Pasai, Pagar Ruyung, Padri, Kerajaan Islam Mataram di Jawa Tengah, Kerajaan Islam Banjarmasin dan sebagainya. Pada saat pemerintahan Kolonial Belanda terdapat beberapa lingkungan Peradilan yang mempunyai susunan, wilayah dan kekuasaan yang berbeda-beda, seperti Peradilan Pemerintah, Peradilan Swapraja, Peradilan Adat yang berlaku untuk daerah di luar Jawa dan Madura, Peradilan Agama dan Peradilan Desa.

Masyarakat Indonesia telah
mengenal peradilan dalam waktu yang lama. Dalam suatu masyarakat yang individunya saling berinteraksi satu dengan yang lain maka akan menimbulkan benturan-benturan kepentingan individu dalam masyarakat. Adanya masyarakat akan diikuti pula adanya aturan atau hukum yang akan diterapkan dan berlaku bagi seluruh anggota masyarakat. Hukum atau aturan ini dibuat agar dapat menciptakan masyarakat yang aman, tenang dan tenteram. Walaupun sudah dibuat suatu aturan namun tetap saja terjadi pelanggaran-pelanggaran hukum atau perselisihan-perselisihan pribadi antar warga masyarakat. ${ }^{1}$

Pemerintah Belanda secara tegas telah membentuk Peradilan Agama berdasarkan Staatsblad Tahun 1882 Nomor 152 tentang Pembentukan

1 Satjipto Raharjo, Ilmu Hukum, Citra Aditya Bakti, Bandung, 1991, hlm. 45. 
Peradilan Agama di Jawa dan Madura. Kekuasaan dan kewenangan Peradilan Agama terbatas pada masalah-masalah muamalah yang bersifat pribadi. Masalahmasalah ibadah seperti puasa, shalat, zakat tidak merupakan masalah yang dibawa ke Peradilan Agama. Hukum muamalah terbatas pada masalah nikah, cerai, rujuk dan lain-lain. Pengakuan Hukum Islam yang berlaku bagi orang Indonesia pada waktu itu menurut penulis Belanda Van de Berg mengemukakan sebuah teori yang disebut Teori Receptio In Complexu yang artinya bagi orang Islam berlaku hukum Islam walaupun terdapat penyimpanganpenyimpangan.

Pada masa awal kemerdekaan Republik Indonesia, Pengadilan Agama masih berpedoman kepada peraturan perundang-undangan Pemerintah Kolonial Belanda berdasarkan aturan peralihan Undang-Undang Dasar 1945. ${ }^{2}$ Pada masa orde baru terdapat perubahan dalam penataan kekuasaan kehakiman di Indonesia. Pada tahun 1970 telah disahkan dan diundangkan Undang-Undang Nomor 14 Tahun 1970 tentang KetentuanKetentuan Pokok Kekuasaan Kehakiman. Kedudukan Peradilan Agama semakin kokoh dengan diundangkannya Undang-

\footnotetext{
${ }^{2}$ M. Idris Ramulyo, Beberapa Masalah tentang Hukum Acara Perdata Peradilan Agama, Ind-Hill.Co, Jakarta, 1991, hlm. 60.
}

Undang Nomor 1 Tahun 1974 tentang Perkawinan dan diundangkannya Peraturan Pemerintah Nomor 9 Tahun 1975 tentang Pelaksanaan UndangUndang Nomor 1 Tahun 1974 tentang Perkawinan.

Perkawinan sendiri dalam Undang-Undnag Nomor 1 Tahun 1974 dikenal adanya perkawinan campuran yang berakibat terhadap status kewarganegaraan anak dari hasil perkawinan campuran atau juga status hak waris. $^{3}$

Berdasarkan Undang-Undang Nomor 14 Tahun 1970, kekuasaan kehakiman di semua lingkungan peradilan berada di bawah Mahkamah Agung.

Pada tahun 1989, Indonesia telah memiliki Undang-Undang Peradilan Agama yaitu Undang-Undang Nomor 7 Tahun 1989. Sejak diundangkannya Undang-Undang Peradilan Agama maka tercapailah keseragaman kekuasaan Pengadilan dalam lingkungan Peradilan Agama di Indonesia. Dari keseluruhan pasal yang terdapat dalam UndangUndang Nomor 7 Tahun 1989 dapat ditemukan beberapa asas yang berlaku pada pengadilan di lingkungan Peradilan

${ }^{3}$ Yati Nurhayati dan Ifrani, " The Legal Consequences Regarding The Execution Of Joint Property Land Obtained Due Transnatiional Marriage In Indonesian Positive Law" Lambung Mangkurat Law Journal, Vol. 3 Issue 1, March (2018), hlm. 127. 
Agama yang salah satunya yaitu Asas Personalitas Keislaman. Pasal 1 ayat (1) menyatakan bahwa "Peradilan Agama adalah peradilan bagi orang-orang yang beragama Islam." Meskipun dalam perjalanannya Undang-Undang Peradilan Agama telah mengalami dua kali perubahan yaitu perubahan pertama Undang-Undang Nomor 3 Tahun 2006 dan sekarang menjadi Undang-Undang Nomor 50 Tahun 2009 tentang perubahan kedua atas Undang-Undang Nomor 7 Tahun 1989 tentang Peradilan Agama, namun asas personalitas keislaman tetap menjadi bagian dari asas umum yang melekat pada Peradilan Agama.

Berdasarkan dengan ketentuan Pasal 49 ayat (1) Undang-Undang Peradilan Agama, Pengadilan Agama yang merupakan pengadilan tingkat pertama untuk memeriksa, memutus dan menyelesaikan perkara-perkara antara orang-orang yang beragama Islam di bidang perkawinan, waris, wasiat, Hibah, Wakaf, Zakat, Infaq, Shadaqah dan Ekonomi Syariah. Kurangnya pemahaman akan asas personalitas keislaman dalam kehidupan bermasyarakat membuat orangorang yang bersengketa khususnya pada perkara perkawinan baik itu dalam hal perceraian atau pembatalan mengalami ketidaksesuaian antara teori dan praktek dilapangan. Bagi seseorang yang memiliki pasangan beragama Islam pada saat sebelum dan setelah menikah maka berlakulah secara otomatis asas umum peradilan agama yaitu asas personalitas keislaman, tetapi bagaimana halnya bagi seseorang yang telah menikah secara Islam dan dalam perjalanan pernikahannya, salah satu diantara mereka beralih agama dari Islam menjadi non Islam, apakah masih berlaku ketentuan asas tersebut bagi mereka, dan bagaimana penerapan asas personalitas keislaman di lingkungan Peradilan Agama pada perkara perkawinan bagi pasangan yang beralih agama? inilah fokus masalah yang akan dibahas dalam tulisan ini.

Dalam tulisan ini, Penulis menggunakan pendekatan Yuridis Normatif (Doctrinal Research) dengan spesifikasi penelitian yang bersifat deskriptif analitis, yaitu dengan cara meneliti bahan pustaka melalui penelusuran dan pengkajian beberapa literatur (berupa data kepustakaan, jurnal, media internet, majalah serta hasil penelitian yang mendukung) yang berhubungan dengan pokok pembahasan yang juga menitikberatkan kepada norma atau kaidah hukum yang terdapat dalam masyarakat, serta menggambarkan gejala hukum (secara faktual dan akurat) mengenai penerapan dan perkembangan asas personalitas keislaman di lingkungan 
Peradilan Agama khususnya dalam bidang perkara perkawinan bagi pasangan yang beralih agama serta melakukan wawancara dengan narasumber dan hakim pengadilan agama khususnya di Pontianak untuk mendapatkan data dan informasi terkait dengan masalah yang penulis angkat dalam penelitian ini. Selain asas personalitas keislaman, Penulis juga menggunakan beberapa teori seperti teori penaatan Hukum yang bertujuan memberikan gambaran bagaimana sesungguhnya Islam telah menata kehidupan manusia dengan hukum-hukum yang telah ditetapkan, teori Penerimaan Otoritas Hukum yang memaparkan bahwa orang yang memeluk Islam akan menerima otoritas hukum Islam dan taat dalam menjalankan syariat Islam dan metode Hermeneutika hukum yang memandang problema hukum dari kacamata sejarah hukum, konstitusi linguistik hukum dan implikasi politik yang dalam pembahasan ini Penulis akan memaparkan mengenai teori Receptio In Complexu yang berkaitan dan saling berhubungan dengan asas umum yang melekat di Peradilan Agama yaitu asas personalitas keislaman.

Manfaat dari hasil penelitian ini diharapkan dapat memberikan masukan dan informasi yang berguna bagi masyarakat pada umumnya dan para pembaca pada khususnya mengenai asas personalitas keislaman yang merupakan asas umum Peradilan Agama dan beberapa pelanggaran asas tersebut di Pengadilan Agama khususnya pada bidang perkara Perkawinan bagi pasangan yang beralih agama, sehingga dapat dilihat penerapan asas personalitas keislaman yang ada di lingkungan Pengadilan Agama Pontianak khususnya, sudah sesuai dengan ketentuan peraturan perundang-undangan di Indonesia atau masih ada pelanggaran yang terjadi pada asas personalitas keislaman.

\section{PEMBAHASAN}

Sekilas tentang Asas Personalitas Keislaman dan Teori Receptio In Complexu

Asas Personalitas Keislaman merupakan dasar pemberlakuan hukum syariah Islam terhadap orang Islam dan badan hukum Islam. Pengertian asas personalitas keislaman merupakan asas pemberlakuan hukum Islam terhadap orang (Person/Mukallaf) yang beragama Islam. Asas personalitas keislaman adalah asas utama yang melekat pada UndangUndang Peradilan Agama yang mempunyai makna bahwa pihak yang tunduk dan dapat ditundukkan kepada kekuasaan di lingkungan Pengadilan Agama adalah hanya mereka yang 
beragama Islam. ${ }^{4}$ Keislaman seseoranglah yang menjadi dasar kewenangan pengadilan di lingkungan Peradilan Agama. $^{5}$ Dengan kata lain, seorang penganut agama non-Islam tidak tunduk dan tidak dapat dipaksakan tunduk kepada kekuasaan Peradilan Agama. ${ }^{6}$

Asas personalitas keislaman diatur dalam Pasal 2, penjelasan umum angka 2 alenia ketiga dan Pasal 49 ayat (1). Dari penggarisan yang dirumuskan tersebut, dapat dilihat bahwa asas personalitas keislaman sekaligus dikaitkan dengan perkara perdata "bidang tertentu", sepanjang mengenai sengketa perkara yang menjadi yurisdiksi lingkungan Peradilan Agama. Jadi, ketundukkan personalita muslim kepada lingkungan peradilan agama "bukan" bersifat umum dan menyeluruh meliputi semua bidang hukum perdata. ${ }^{7}$

Pengadilan Agama merupakan pengadilan tingkat pertama untuk memeriksa, memutus dan menyelesaikan perkara-perkara antara orang yang beragama Islam di bidang :

a. Perkawinan;

4 Yahya Harahap, Kedudukan Kewenangan dan Acara Peradilan Agama, Sinar Grafika, Jakarta, 2001, hlm. 56.

5 Jaenal Aripin, Peradilan Agama dalam Bingkai Reformasi Hukum di Indonesia, Kencana, Jakarta, 2008, hlm. 349.

${ }^{6}$ Sulaikin Lubis et. Al., Hukum Acara Perdata Peradilan Agama di Indonesia, Kencana, Jakarta, 2005, hlm. 59.

${ }^{7}$ Yahya Harahap, Op. Cit, hlm. 56-57.
b. Waris;
c. Wasiat;
d. Hibah;
e. Wakaf;
f. Zakat;
g. Infaq;
h. Shadaqah dan;
i. Ekonomi Syariah.

Apa yang tercantum dalam Penjelasan Umum tersebut sama dengan yang dirumuskan dalam Pasal 49 ayat (1) Undang-Undang Nomor 7 Tahun 1989 jo Undang-Undang Nomor 3 Tahun 2006 yang sekarang menjadi Undang-Undang Nomor 50 Tahun 2009 tentang Peradilan Agama.

Dengan demikian asas personalitas keislaman dapat dimaknai dengan penegasan sebagai berikut:

1. Pihak-pihak yang berperkara harus sama-sama Islam;

2. Perkara-perkara yang disengketakan harus mengenai perkara perkawinan, waris, wasiat, hibah, wakaf, zakat, infaq, shadaqah dan ekonomi syariah;

3. Hubungan hukum yang melandasi bidang-bidang keperdataan tersebut adalah hukum Islam. ${ }^{8}$

Latar belakang munculnya asas personalitas keislaman ini berawal karena

\footnotetext{
${ }^{8}$ Jaenal Aripin, Op.Cit, hlm. 249.
} 
adanya teori Receptio in complexu yang dikemukakan oleh Van Den Berg. Asas ini merupakan pembaharuan atau pengembangan dari teori Receptio In Complexu. Dengan adanya teori ini terhadap setiap orang berlaku hukum agama yang dianutnya berdasarkan asas ini maka muncullah asas personalitas keislaman. Asas ini mengajarkan bahwa terhadap orang Islam berlaku hukum Islam dan jika terjadi pelanggaran sengketa diselesaikan menurut hukum Islam oleh hakim Pengadilan agama Islam. ${ }^{9}$ Teori ini menyatakan bahwa hukum adat bangsa Indonesia adalah hukum agamanya masing-masing, jadi hukum yang berlaku bagi pribumi yang beragama Islam adalah hukum Islam, sedangkan hukum yang berlaku bagi penduduk asli yang beragama khatolik adalah hukum atau ketentuan agamanya, demikian juga halnya dengan penganut agama lain, teori ini yang dikenal dengan teori Receptio In Complexu (RIC).

Materi teori ini kemudian dimuat dalam Pasal 75 RR (Regeling Reglement) tahun 1855. Pada Pasal 75 ayat 3 RR ini berbunyi "Oleh Hakim Indonesia itu hendaklah diberlakukan undang-undang

${ }^{9}$ A. Mukti Arto, Garis Batas Kekuasaan Pengadilan Agama dan Pengadilan Negeri (Penerapan Asas Personalitas Keislaman Sebagai Dasar Penentuan Kekuasaan Pengadilan Agama), Jurnal Varia Peradilan Edisi November 2008. agama (Jadsdiendnge Wetten) dan kebiasaan penduduk Indonesia itu”.

Pada masa teori ini berlaku, kemudian antara lain Staatsblad Tahun 1882 Nomor 152 tentang pembentukan Pengadilan Agama (Priensterand) disamping Pengadilan Negeri (Landraad). Berdasarkan Pasal 75 dengan mengacu kepada teori Receptio In Complexu hukum waris yang berlaku bagi orang Islam adalah Hukum Waris Islam dan menjadi kompetensi (wewenang) peradilan Agama.

Pada mulanya, politik kolonial Belanda cukup menguntungkan posisi hukum Islam, setidaknya sampai akhir abad ke-19 M dikeluarkannya Staatsblad Nomor 152 Tahun 1882 yang mengatur sekaligus mengakui adanya lembaga Peradilan Agama di Jawa dan Madura, merupakan indikasi kuat diterimanya hukum Islam oleh pemerintah kolonial Belanda. Dari sinilah muncul teori Receptio In Complexu yang dikembangkan oleh Lodewijk Willem Christian Van Den Berg (1845-1927). Menurut ahli hukum Belanda ini, hukum mengikuti agama yang dianut seseorang. Jika orang itu memeluk agama Islam, maka hukum Islamlah yang berlaku baginya. Dengan adanya teori ini maka hukum Islam sejajar dengan sistem hukum lainnya. Tetapi kondisi di atas tidak 
berlangsung lama, seiring dengan perubahan orientasi politik Belanda, kemudian dilakukan upaya penyempitan ruang gerak dan perkembangan hukum Islam. Perubahan politik ini telah mengantarkan hukum Islam pada posisi yang kritis. Melalui ide Van Vollenhoven (1874-1933) dan C.S. Hurgronje (18571936) yang dikemas dalam konsep Het Indische Adatrecht yang dikenal dengan teori Receptie, dengan adanya teori ini hukum Islam dapat berlaku apabila telah diresepsi oleh hukum adat. Berdasarkan teori inilah hukum adat yang menentukan ada tidaknya hukum Islam. Dengan adanya teori Receptie ini, Belanda cukup punya alasan untuk membentuk sebuah komisi yang bertugas meninjau kembali wewenang Pengadilan Agama di Jawa dan Madura. Dengan bekal sebuah rekomendasi (usulan) dari komisi ini, lahirlah Staatsblad Nomor 116 Tahun 1937 yang berisi pencabutan wewenang Pengadilan Agama untuk menangani masalah waris dan lainnya. Perkaraperkara ini kemudian dilimpahkan kewenangannya kepada Landraad (Pengadilan Negeri).

Hazairin, seorang ahli hukum adat dan hukum Islam terkemuka dari Fakultas Hukum Universitas Indonesia dan merupakan salah seorang murid Ter Haar tetapi tidak sepaham dengan ajaran yang dikembangkan oleh gurunya itu menyatakan bahwa teori Receptie yang diciptakan oleh kekuasaan kolonial Belanda untuk merintangi kemajuan Islam di Indonesia itu adalah "Teori Iblis" dan mengatakan bahwa teori Receptie tidak berlaku lagi. Hazairin mengemukakan teori dengan nama teori Receptie Exit yang berarti bahwa teori resepsi itu harus keluar dari Indonesia dan ini merupakan teori Iblis yang merusak iman orang Islam dan menentang Al-Qur'an.

Sajuti Thalib seorang murid Hazairin mengemukakan teori yang senada dengan teori Resepsi exit, yaitu teori receptio a contrario (penerimaan yang sebaliknya). Menurut teori ini hukum Islamlah yang berlaku bagi umat Islam dan hukum adat baru bisa berlaku jika tidak bertentangan dengan hukum Islam. $^{10}$

\section{Teori Penaatan Hukum, Teori Otoritas}

\section{Hukum dan Teori Lex Posteriori Derogat Legi Priori}

Dalam penelitian ini, selain asas personalitas keislaman dan teori Receptio In Complexu, Penulis juga menggunakan beberapa teori lain sebagai bagian dari pemecahan masalah yang diangkat. Teori Penaatan Hukum yaitu teori-teori

${ }^{10}$ Sayuti Thalib, Receptio a Contrario, Hubungan Hukum Adat dengan Hukum Islam, Bina Aksara, Jakarta, 1985, hlm. 62. 
pemberlakuan hukum Islam yang sangat berkaitan dengan proses bagaimana unsurunsur hukum Islam itu dapat menjadi hukum positif atau bagian dari hukum nasional, disamping hukum adat dan hukum barat. Adanya politisasi hukum yang dilakukan oleh Kolonial Belanda kearah mereduksi syariat Islam serta menjauhkan dari masyarakatnya sehingga menyebabkan hukum Islam sampai saat ini selalu terpinggirkan dalam proses positivasi hukum dalam perspektif tata hukum Indonesia. Ajaran Islam tentang penaatan hukum memberi gambaran, bagaimana sesungguhnya Islam telah menata kehidupan manusia ini dengan hukum-hukum yang telah ditetapkan. Teori atau ajaran tentang penaatan hukum menurut perspektif Islam bersumber dari Allah sebagai pencipta syariat dalam bentuk wahyu, yaitu al-Qur'an. Ia merupakan hukum normatif bersifat universal dan berlaku untuk seluruh manusia tanpa membedakan kedudukan, ras, politik, dan sosial-budaya. ${ }^{11}$

Ajaran tentang penaatan hukum ini menyatakan bahwa bagi setiap orang yang beriman agar menjalankan syariatnya secara kaffah. Beberapa prinsip yang tercantum dalam Al-Qur'an tentang

11 A. Rahmad Rosyadi dan M. Rais Ahmad, Formulasi Syari'at Islam Dalam Perspektif Tata Hukum Indonesia, Ghalia Indonesia, Bogor, 2006, hlm. 67. penataan dan penerapan hukum Islam, menegaskan bahwa orang Islam pada dasarnya diperintahkan supaya taat kepada Allah dan rasul-Nya serta kepada pemerintah. Orang Islam tidak dibenarkan mengambil pilihan hukum lain manakala Allah dan rasul-Nya telah menetapkan hukum yang pasti dan jelas. Apabila mengambil pilihan hukum selain syariat Islam, maka dianggap zalim, kafir, dan fasik Oleh karena itu dari segi syariat Islam semestinya berlaku teori penataan hukum, bahwa setiap orang Islam berlaku hukum Islam dan wajib menjalankannya sebagai tuntutan akidah.

Teori Penerimaan Otoritas Hukum diperkenalkan oleh seorang orientalis Kristen, H.A.R. Gibb, dalam bukunya The Modern Ternds of Islam, seperti dikutip H. Ichtijanto bahwa orang Islam jika menerima Islam sebagai agamanya, ia akan menerima otoritas hukum Islam kepada dirinya. Berdasarkan teori ini, secara sosilogis, orang yang memeluk Islam akan menerima otoritas hukum Islam dan taat dalam menjalankan syariat Islam. Namun ketaatan ini akan berbeda satu dengan lainnya, dan sangat bergantung pada tingkat ketakwaan masing-masing.

Selain Gibb, Charles J. Adams (1950), mengungkapkan bahwa hukum Islam merupakan subjek terpenting dalam 
kajian Islam karena sifatnya yang menyeluruh, meliputi semua bidang hidup dan kehidupan muslim. Berbeda degan cara mempelajari hukum-hukum lain, studi tentang hukum Islam memerlukan pendekatan khusus, sebab yang termasuk bidang hukum Islam itu bukan hanya apa yang disebut dengan istilah law dalam hukum Eropa, tetapi juga termasuk masalah sosial lain diluar wilayah yang dikatakan law itu.

Sebagai sebuah fakta yang terjadi pada masyarakat yang telah menerima Islam, semua orang Islam akan terus menjalankan syariat berdasarkan akidah yang dianutnya. Akan sangat sulit memisahkan masyarakat Islam dengan syariatnya yang menjadi tuntutan hukum dan moral dalam kehidupannya. Pada masyarakat Indonesia yang keislamannya dianut oleh fanatisme ajaran atau ketokohannya, akan selalu mempertahankan syariat dan akidahnya sampai mati.

Lex posterior derogat legi priori atau Lex posterior derogate legi anteriori mempunyai arti bahwa undang-undang yang lebih baru mengenyampingkan undang-undang yang lama. Dalam penelitian yang dilakukan oleh penulis, terdapat beberapa peraturan perundangundangan yang telah berubah seperti undang-undang nomor 7 tahun 1989 tentang peradilan agama yang mana telah dilakukan perubahan sebanyak dua kali yang pertama diubah dengan undangundang nomor 3 tahun 2006 dan yang kedua yaitu undang-undang nomor 50 tahun 2009.

\section{Penerapan Asas Personalitas}

Keislaman di Lingkungan Peradilan Agama Pontianak Bagi Pasangan yang Beralih Agama

Peradilan Agama sebagai lembaga hukum yang berdiri sendiri dan mempunyai kedudukan yang kuat dalam masyarakat. Kerajaan-kerajaan Islam yang pernah berdir, telah melaksanakan hukum Islam dan melembagakan sistem peradilannya sebagai bagian yang tidak terpisahkan dengan keseluruhan sistem pemerintahan diwilayah kekuasaannya.

Indonesia bukan negara agama juga bukan negara sekuler, maka perjuangan hukum Islam sebagai bagian dari dasar hukum negara adalah dengan memahami aspek filosofi yang tercermin dalam dalil-dalil. ${ }^{12}$ Atas dasar keyakinan inilah maka para ahli hukum Belanda yang dipelopori oleh L.W.C. Van Den Berg berkembang pendapat bahwa hukum

\footnotetext{
${ }^{12}$ Nurhayati, Yati. "Posisi Agama dalam Ranah Politik di Indonesia." Al Adl: Jurnal Hukum, Volume 5 Nomor 9 (2013), hlm, 14.
} 
yang berlaku bagi orang Indonesia asli adalah Undang-Undang agama mereka yakni Hukum Islam. Teori ini kemudian dikenal dengan teori Receptio in complexu yang sejak tahun 1855 telah didukung peraturan perundang-undangan Hindia Belanda melalui Pasal 75, 78 dan 109 RR (Stbl. 1855 No. 2). Karena L.W.C. Van Den Berg adalah konseptor Staatsblad Nomor 152, maka dapat dikatakan bahwa alasan yang disebutkan merupakan latar belakang dan dasar pemikiran yang berpusat pada realita historis, kenyataan sosiologis kemudian diberikan legitimasi yuridis oleh pemerintahan Belanda bagi berdirinya Peradilan Agama di Indonesia.

Dalam penerapannya, asas personalitas keislaman ini dianut dan dikembangkan dalam Undang-Undang Nomor 7 Tahun 1989 tentang Peradilan Agama dalam ruang lingkup yang terbatas, yaitu dalam penjelasan umum angka 2 alenia ketiga dikatakan bahwa Pengadilan Agama merupakan pengadilan tingkat pertama untuk memeriksa, memutus dan menyelesaikan perkaraperkara antara orang-orang yang beragama Islam dibidang perkawinan, kewarisan, wasiat, hibah, wakaf dan shadaqah berdasarkan hukum Islam. Kata berdasarkan hukum Islam tersebut menunjukkan bahwa terhadap orangorang Islam dalam perkara tersebut secara yuridis berlaku hukum Islam dan jika terjadi sengketa harus diselesaikan secara atau berdasarkan ketentuan hukum Islam.

Asas personalitas keislaman ini kemudian dipertegas dan diperluas berlakunya dalam Undang-Undang Nomor 50 Tahun 2009 (Nomor 3 Tahun 2006 tentang perubahan Undang-Undang Nomor 7 Tahun 1989). Dipertegas yakni dengan dihapuskannya pilihan hukum dalam pembagian warisan dan dihilangkannya klausul-klausul yang menyulitkan dalam perkara warisan hibah dan wasiat dengan kata-kata yang dilakukan berdasarkan hukum Islam pada Pasal 49 yang lama. Diperluas yakni pertama dengan ditambahkannya kekuasaan Pengadilan Agama atas perkara zakat, infaq dan ekonomi syariah. Kemudian adanya kemungkinan masuknya perkara pidana pelanggaran dalam perkara tersebut ke dalam wewenang Pengadilan Agama, sebagaimana ditegaskan dalam penjelasan umum Undang-Undang Nomor 3 Tahun 2006 tersebut.

Berdasarkan asas personalitas keislaman tersebut, khususnya dalam perkara dibidang perkawinan, ketika seseorang sudah memeluk agama Islam sesuai dengan ketentuan hukum Islam dan akad perkawinan dilakukan secara Islam dan ketentuan Hukum Islam, 
dilangsungkan dihadapan dan dicatatkan pada PPN KUA kecamatan yang berwenang, otomatis berlakulah asas personalitas keislaman dalam dirinya. Walaupun sepanjang perjalanan perkawinannya mengalami sengketa atau pelanggaran, seperti beralih agama (dari agama Islam menjadi non Islam) yang mengakibatkan sampai kepada perceraian, pembatalan perkawinan, pembagian harta bersama akibat putusnya perkawinan dan sebagainya, apabila terjadi sengketa diselesaikan menurut ketentuan hukum Islam oleh Pengadilan Agama. ${ }^{13}$

Dalam studi kasus Putusan Mahkamah Agung Nomor 726K/SIP/1976 terdapat suatu pelanggaran asas personalitas keislaman dalam perkara pembatalan perkawinan yang mengakibatkan adanya perbedaan sudut pandang antar dua lembaga peradilan yaitu Pengadilan Agama dan Pengadilan Negeri. Adanya pasangan yang secara Islam telah melaksanakan perkawinan tetapi dimintakan pembatalan oleh orang tuanya dikarenakan anaknya belum beragama Islam dan gugatan permohonan pembatalan tersebut diajukan ke Pengadilan Negeri dan sampai kepada Putusan akhir, hakim mengabulkan

13 A. Mukti Arto, Peradilan Agama dalam Sistem Ketatnegaraan Indonesia, Pustaka Pelajar, Yogyakarta, 2012, hlm. 176. pembatalan tersebut padahal para pihak yang melaksanakan perkawinan telah melekat asas personalitas keislaman pada dirinya. Berdasarkan ketentuan asas personalitas keislaman sudah terlihat jelas bahwa asas ini melekat pada perkara yang oleh Undang-undang dijadikan dasar untuk menentukan kekuasaan pengadilan agama. Dengan kata lain, apabila suatu perkara berkenaan dengan hal-hal yang terhadapnya melekat asas personalitas keislaman maka perkara tersebut masuk menjadi kekuasaan absolut Pengadilan Agama, meskipun dalam hal ini para pihak yang berperkara setelah melakukan perkawinan secara Islam dan ketentuan hukum Islam dalam mengarungi bahtera rumah tangga beralih agama dari Islam menjadi non Islam, tetap saja yurisdiksi dalam perkara yang diajukan terhadapnya masuk kedalam ruang lingkup lingkungan Pengadilan Agama.

Dalam penelitian ini Penulis juga melakukan wawancara dengan Hakim Pengadilan Agama Pontianak, menurut Rustam A. Kaderi, keberadaan KUHPerdata atau yang biasa kita kenal dengan B.W. sudah tidak cocok lagi dengan keadaan yang ada di Indonesia bahkan ada beberapa Pasal yang berkaitan dengan hal perkawinan dikatakan sudah tidak berlaku lagi, seperti Pasal 108, Pasal 109 dan Pasal 110 B.W. sehingga B.W. 
hanya merupakan kumpulan aturan-aturan tertulis dan tidak berfungsi sebagai norma hukum, maka sangat tidak tepat jika pasangan yang beralih agama diterapkan Pasal-pasal yang terdapat dalam KUHPerdata. Indonesia telah mempunyai Undang-Undang Perkawinan yang telah berlaku pada tahun 1974 yang dapat memberikan kemudahan bagi pasangan yang beralih agama untuk menyelesaikan sengketa dibidang perkawinannya ke ranah pengadilan. Untuk menentukan kewenangan pengadilan mana yang berhak mengadili perkara dibidang perkawinan yang dilangsungkan oleh pasangan yang beralih agama, terlebih dahulu dapat akan dibahas mengenai kewenangan masing-masing pengadilan baik pengadilan agama dan pengadilan negeri. Tujuan utama membahas yuridiksi atau kewenangan mengadili adalah untuk memberikan penjelasan mengenai masalah pengadilan mana yang benar dan tepat mengadili suatu sengketa yang muncul, agar pengajuan dan penyampaiannya kepada pengadilan tidak keliru. Apabila yang diajukan keliru, mengakibatkan gugatan tidak dapat diterima atas alasan pengadilan yang dituju, tidak berwenang mengadilinya atau dapat dikatakan gugatan yang diajukan diluar daripada yuridiksi pengadilan tersebut. Kekeliruan mengajukan gugatan kepada lingkungan Peradilan atau pengadilan yang tidak berwenang mengakibatkan gugatan salah alamat sehingga tidak sah dan dinyatakan tidak dapat diterima atas alasan gugatan yang diajukan tidak termasuk yuridiksi absolut atau relatif pengadilan yang bersangkutan. ${ }^{14}$

Bagi pasangan yang beralih agama setelah melangsungkan perkawinan secara Islam dan berdasarkan ketentuan hukum Islam, kemudian dalam perjalanan perkawinannya terjadi suatu hal yang tidak diinginkan misalnya pembatalan perkawinan dan sebagainya, maka terkait dengan yuridiksi pengadilan yang berwenang untuk menangani permasalahan mereka adalah masuk dalam ranah Pengadilan Agama. Sesuai dengan asas umum Pengadilan Agama, yaitu asas personalitas keislaman, maka secara otomatis melekatlah asas tersebut pada pasangan yang melakukan perkawinan secara Islam tersebut meskipun dalam perjalanannya telah beralih agama. Menurut Hakim Pengadilan Agama Pontianak, minimnya sosialisasi mengenai Asas Personalitas keislaman kepada masyarakat mengakibatkan kurangnya pengetahuan akan hukum khususnya berkaitan dengan perkara-perkara perdata

14 Yahya Harahap, Hukum Acara Perdata, Sinar Grafika, Jakarta, 2005, hlm. 180. 
tertentu. Terkadang menimbulkan kesalahan dalam menentukan pengadilan mana yang berwenang dalam penyelesaian perkara dibidang perkawinan khususnya pada pasangan yang beralih agama sehingga menyebabkan penerapan asas personalitas keislaman tidak berjalan sebagaimana mestinya seperti yang sudah ditentukan dalam peraturan perundangundangan.

\section{PENUTUP}

\section{Kesimpulan dan Saran}

Asas personalitas keislaman merupakan asas umum yang melekat pada lembaga Pengadilan Agama. Ketika suatu perkawinan telah dilangsungkan secara Islam, maka secara otomatis telah melekatlah asas personalitas keislaman dalam dirinya. Berdasarkan asas ini, status agama diawal terjadinya suatu perbuatan hukum menentukan jika terjadi sengketa terhadap perkawinannya, dan sudah semestinya diajukan dan menjadi kewenangan absolut Pengadilan Agama bukan Pengadilan Negeri. Adanya putusan Mahkamah Agung Nomor 726K/SIP/1976 mengenai pembatalan perkawinan yang dilakukan pasangan yang beralih agama tidak tepat karena pasangan tersebut telah beragama Islam pada saat melakukan perkawinannya, secara otomatis telah berlaku asas personalitas keislaman terhadap mereka. Adanya pihak yang mengajukan permohonan pembatalan tersebut tidak sesuai dengan kewenangan absolut suatu Pengadilan, karena diajukan kepada Pengadilan Negeri, seharusnya merupakan kewenangan absolut Pengadilan Agama yang berhak untuk memeriksa perkara.

Hal seperti ini yang menyebabkan penerapan asas personalitas keislaman belum sepenuhnya diterapkan sesuai dengan ketentuan peraturan perundangundangan yang berlaku di Indonesia. Perlunya sosialisasi akan asas personalitas keislaman di lingkungan masyarakat khususnya di Pontianak agar apabila terjadi suatu sengketa dikemudian hari bagi pasangan yang beralih agama, tidak terjadi kesalahan atau kekeliruan dalam mengajukan suatu gugatan atau permohonan dan tidak terjadi kekeliruan dalam memilih pengadilan mana yang berhak untuk menangani perkara-perkara dibidang perkawinan bagi pasangan yang beralih agama.

Mahkamah Agung yang merupakan lembaga yang melakukan pengawasan tertinggi terhadap jalannya peradilan di semua lingkungan peradilan termasuk pengawasan terhadap Pengadilan Agama dan Pengadilan Negeri dapat memberikan suatu pertimbanganpertimbangan tentang pengaturan hukum 
yang sesuai dengan kewenangan absolut dan relatif yang ada pada Pengadilan Negeri dan Pengadilan Agama sehingga tidak ada perbedaan dalam sudut pandang hakim-hakim dalam menyelesaikan perkara yang berkaitan dengan asas personalitas keislaman dan perkara perdata dibidang perkawinan bagi pasangan yang beralih agama. Sehingga penerapan asas personalitas keislaman di lingkungan Pengadilan Agama dapat dijalankan sesuai dengan peraturan perundang-undangan dan tidak ada lagi pelanggaran yang terjadi.

\section{DAFTAR PUSTAKA}

Aripin, Jaenal, 2008, Peradilan Agama dalam Bingkai Reformasi Hukum di Indonesia, Kencana, Jakarta.

Arto, A. Mukti, 2012, Peradilan Agama Dalam Sistem Ketatanegaraan Indonesia, Pustaka Pelajar, Yogyakarta.

Arto, A. Mukti, 2008, Garis Batas Kekuasaan Pengadilan Agama dan Pengadilan Negeri (Penerapan Asas Personalitas Keislaman Sebagai Dasar Penentuan Kekuasaan Pengadilan Agama), di muat dalam Jurnal Varia Pengadilan edisi November 2008.
Hamami, Taufiq, 2012, Peradilan Agama Dalam Reformasi Kekuasaan Kehakiman Di Indonesia Pasca Amandemen Ketiga UUD 1945, PT. Tata Nusa, Jakarta.

Harahap, Yahya, 2001, Kedudukan Kewenangan dan Acara Peradilan Agama, Sinar Grafika, Jakarta.

2005, Hukum Acara Perdata, Jakarta : Sinar Grafika.

Idris Ramulyo, Muhammad, 1991, Beberapa Masalah tentang Hukum Acara Perdata Peradilan Agama, Ind-Hill.Co, Jakarta,

Lubis, Sulaikin et. Al., 2005, Hukum Acara Perdata Peradilan Agama di Indonesia, Kencana, Jakarta.

Raharjo, Satjipto, 1991, Ilmu Hukum, Citra Aditya Bakti, Bandung.

Rosyadi, A. Rahmad dan M. Rais Ahmad, 2006, Formulasi Syari'at Islam Dalam Perspektif Tata Hukum Indonesia, Ghalia Indonesia, Bogor.

Sunggono, Bambang, 1997, Metodologi Penelitian Hukum, Rajawali Press, Jakarta.

Thalib, Sayuti, 1985, Receptio a Contrario, Hubungan Hukum Adat dengan Hukum Islam, Bina Aksara, Jakarta.

\section{Jurnal}

Yati Nurhayati dan Ifrani, " The Legal Consequences Regarding The Execution Of Joint Property Land Obtained Due Transnatiional Marriage In Indonesian Positive Law" Lambung Mangkurat Law 
Journal, Vol. 3 Issue 1, March (2018)

http://lamlaj.ulm.ac.id/web/index.p hp/abc/article

Nurhayati, Yati. "Posisi Agama dalam Ranah Politik di Indonesia." $A l$ Adl: Jurnal Hukum 5.9 (2013).

\section{Peraturan Perundang-Undangan :}

Undang-Undang Nomor 1 Tahun 1974 tentang Perkawinan;

Undang-Undang Nomor 48 Tahun 2009

Tentang Kekuasaan Kehakiman;

Undang-undang Nomor 50 Tahun 2009 tentang Perubahan Kedua Atas Undang-undang Nomor 7 Tahun 1989 tentang Peradilan Agama;

Instruksi Presiden Nomor 1 Tahun 1991 tentang Kompilasi Hukum Islam;

PP Nomor 9 Tahun 1975 Tentang Pelaksanaan Undang-Undang Nomor 1 Tahun 1974;

Putusan Mahkamah Agung Nomor: 726K/Sip/1976. 